\title{
THE EFFECT OF PRICE, QUALITY OF SERVICE, BRAND IMAGE OF INTERNET PRODUCT VSAT IP BROADBAND QUOTA TO ALFAMART CUSTOMER SATISFACTION ${ }^{1}$
}

\author{
Imam Subekhi, Baruna Hadibrata \\ Program Pascasarjana Universitas Mercu Buana \\ DOI: 10.37648/ijrst.v10i02.006
}

Received: 02 ${ }^{\text {nd }}$ March, 2020; Accepted: 29 ${ }^{\text {th }}$ April, 2020; Published: 02 ${ }^{\text {nd }}$ May, 2020

\begin{abstract}
The aim of this research was to determine the effect of Price, Quality of Service and Brand Image on Customer Satisfaction of Alfamart Customer in using VSAT IP Broadband Quota service of PT Telkomsat. Number of respondents in this research is 248 respondents who work in Alfamart retail stores especially Jabodetabek area. The research method uses a questionnaire with SEM (Structural Equation Modelling) data analysis which is described in PLS (Partial Least Square) SEM Application. The result of this research showed that the Price variable has a positive and significant effect on Customer Satisfaction. Quality of Service variable has a positive and significant effect on Customer Satisfaction. Then the Brand Image variable also has a positive and significant effect on Customer Satisfaction.

Keywords : Price; Quality of Service; Brand Image; Customer Satisfaction; Evaluation of PLS - SEM Model
\end{abstract}

\section{INTRODUCTION}

The development of internet user in Indonesia increase every year, based on the data research in 2017 by Kadata databoks that figure 1 shows the internet user have reached 143.3 million peoples where the majority of users are in urban areas, while for sub urban or rural areas, there is limited infrastructure. One of alternatives technology is satellite technology for people needs and business in industrial area for natural resource management which has high purchasing.

\footnotetext{
${ }^{1}$ How to cite the artcle: Subekhi I., Hadibrata B., The Effect of Price, Quality Of Service, Brand Image of Internet Product VSAT IP Broadband Quota to Alfamart Customer Satisfaction, IJRST, Apr-Jun 2020, Vol 10, Issue 2, 66-86, DOI: http://doi.org/10.37648/ijrst.v10i02.006
} 


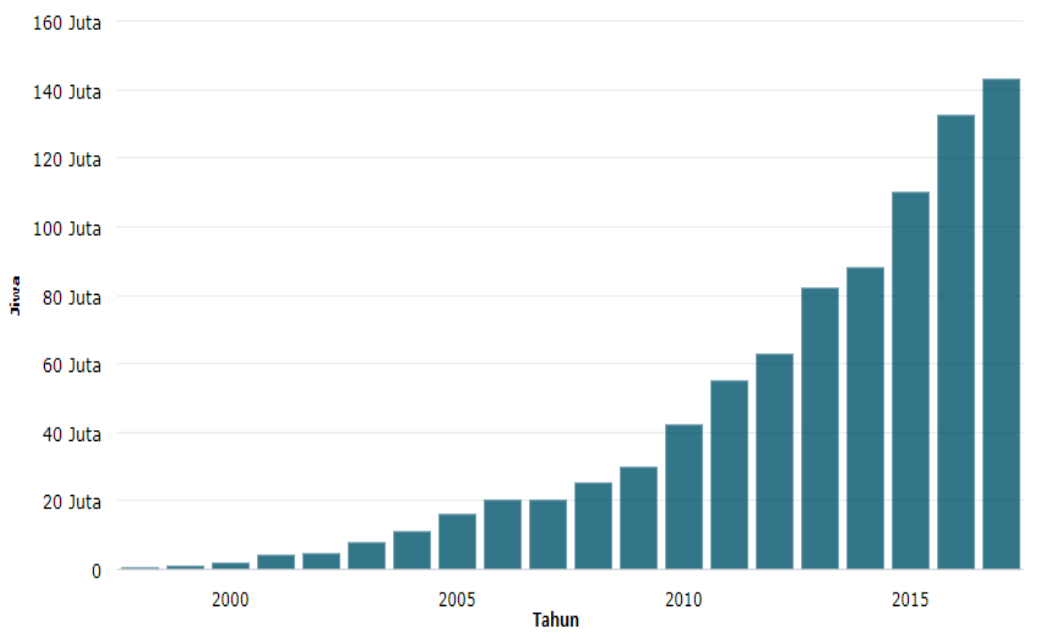

Figure 1. Internet User in Indonesia

Source : data databoks.katadata.co.id (1998 - 2017)

Mangoesky provides a broadband internet service via satellite media (VSAT IP). Not only internet connection access, Mangoesky also provides free FTA channel. Mangoesky gives a solution to retail customer, residential, café/villa, UKM/SME, School, Government Office, and Corporation in rural or sub-urban areas that are not covered by ADSL, Fiber, and high-speed mobile access services. One of Mangoesky's retail customers is Alfamart. The marketing strategy use direct strategy. Based on source of databoks.katadata.co.id in 2017 that number of Alfamart stores increase every year. On December 2016, number of Alfamart stores is 12,300 stores, and on September 2017 increased to 13,400 stores, which means that there was an enhancement 1,100 stores.

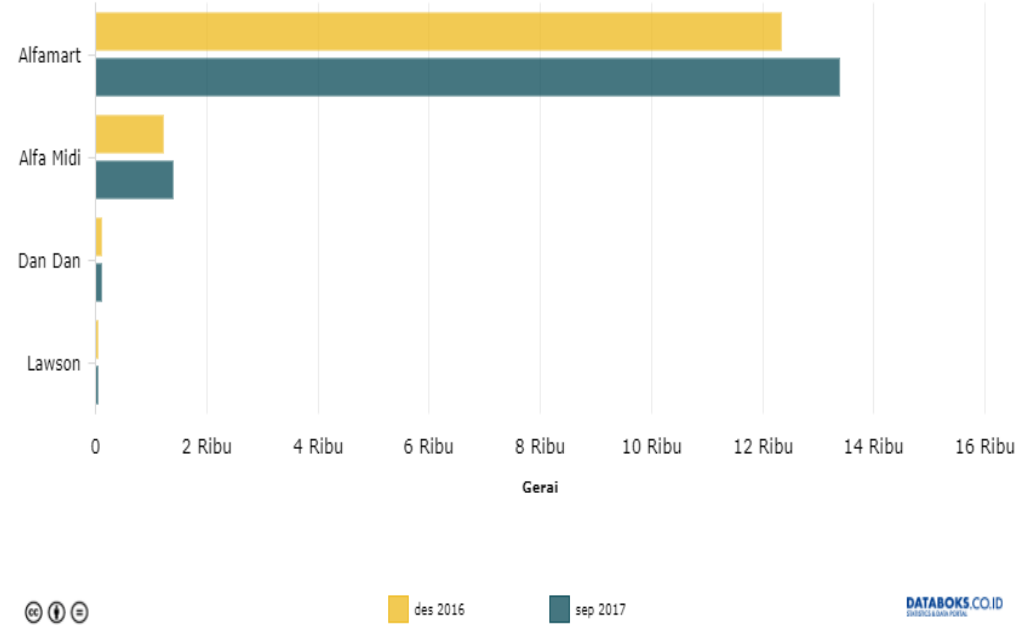

Figure 2. Number of Alfamart Stores

Source : data databoks.katadata.co.id (2016 - 2017$)$

The fact shows that satellite broadband internet service of VSAT Mangoesky for retail Alfamart is still required; Table 1 shows the growth of Alfamart customer every year. There is an opportunity for Metrasat by VSAT IP Broadband Quota product to increase market share. However, the number of orders has decreased dramatically in 2018. 
Table 1. Alfamart Customer Growth (2015 - 2018)

\begin{tabular}{ccc}
\hline No & Year & Number of Link \\
\hline 1 & 2015 & 283 \\
2 & 2016 & 508 \\
3 & 2017 & 321 \\
4 & 2018 & 111 \\
& Total & 1.223 \\
& Link & \\
\hline
\end{tabular}

Source : Data Metrasat (2018)

CSI value is more than 50\% which means that the respondent is satisfied, but if the CSI value is less than $50 \%$ which means that the respondent is not satisfied. The CSI value in this research is divided into five criteria, from not satisfied criteria to very satisfied criteria (Fitriana, et all.2014).

Table 2. Value Criteria of Customer Satisfaction Index (CSI)

\begin{tabular}{ccc}
\hline No & Index & Interpretation \\
\hline 1 & $81 \%-100 \%$ & Very Satisfied \\
2 & $66 \%-80.99 \%$ & Satisfied \\
3 & $51 \%-65.99 \%$ & Quite Satisfied \\
4 & $35 \%-50.99 \%$ & Less Satisfied \\
5 & $0 \%-34.99 \%$ & Not Satisfied \\
\hline \multicolumn{3}{c}{ Source : Fitriana, et all, 2014 }
\end{tabular}

Based on the Metrasat research, level of satisfaction for internet speed of VSAT IP Broadband Quota, figure 3 shows that customers are quite satisfied by $39 \%$ in 2018 , which means that the customers are not satisfied.

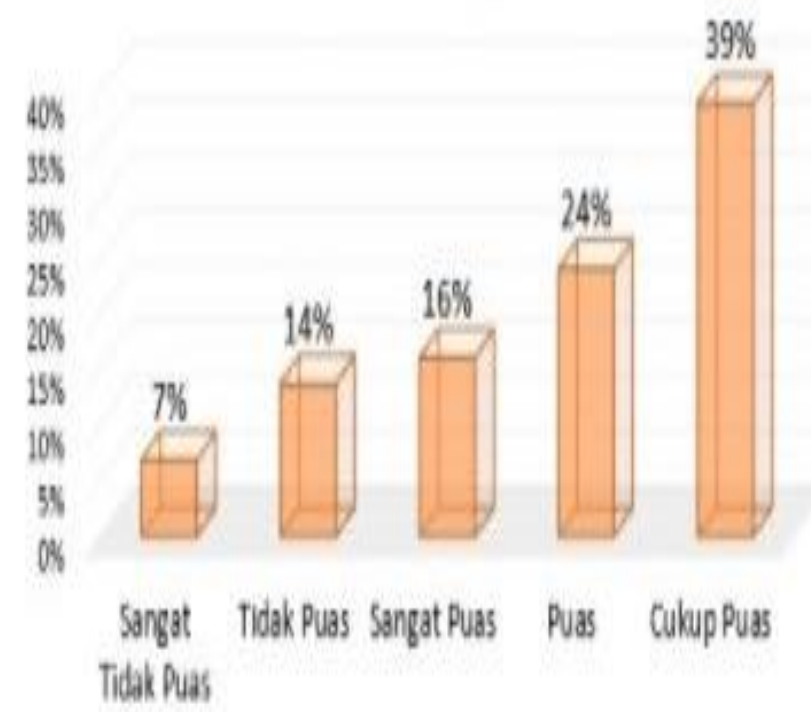

Figure 3. Level of Satisfaction for Internet Service of VSAT IP Broadband Source : Data Metrasat (2018) 
Based on the pre-survey of the author, research object is 30 respondents, shown in figure 4 .

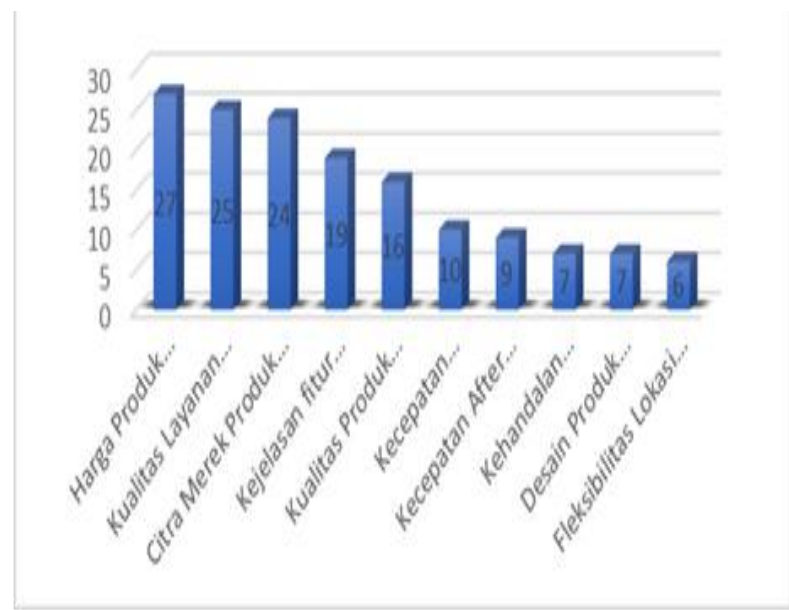

Figure 4. Pre Survey Customer Satisfaction Factors

Source : Data Pra Survey (2019)

Pre-survey was held on 12 - 22 May 2019. Result for customer satisfaction factor is price with 20 respondents or $90 \%$, quality of service with 25 respondents or $83.3 \%$, and brand image with 24 respondents or $80 \%$. Level of satisfaction for VSAT IP Broadband Quota product is not satisfied $73.3 \%$ or 22 respondents and satisfied $26.7 \%$ or 8 respondents. Based on the background, the author examine the effect of price, quality of service and brand image to all Alfamart customer satisfaction in Indoesia use VSAT IP Broadband Quota. Therefore, the author propose a research related to effect of price, quality of service and brand image to Alfamart customer satisfaction use VSAT IP Broadband Quota service at PT Telkomsat, Metrasat Division.

Identification of Problem. Identification of research problem is : (1) Price decreases customer satisfaction. (2) Quality of service decreases customer satisfaction. (3) VSAT IP Broadband Quota service of Metrasat did not show the appropriate brand image to Alfamart customers and as a last choice besides fiber optic. (4) Company strategy is not optimal related to price, quality of service, and brand image.

Purpose of Research. Purpose of research is : (1) To analyze the effect of price to Alfamart customer satisfaction use VSAT IP Broadband Quota. (2) To analyze the effect of quality of service to Alfamart customer satisfaction use VSAT IP Broadband Quota. (3) To analyze the effect of brand image to Alfamart customer satisfaction use VSAT IP Broadband Quota.
Importance of Research. The research is for a reference and additional information for similar topic in the future. The research is to help VSAT IP Broadband Quota provider to find the factors that can affect customer satisfaction and can be used as marketing strategy in the future.

\section{BASIC THEORY}

Internet Product VSAT IP Broadband Quota according to the product catalog (PT Telkomsat:11) VSAT IP Broadband Quota is a broadband internet service provided to internet users through satellite media (VSAT IP) with quota-based differentiation. VSAT IP Broadband Quota provides solution for retail, residential, café/villa, UKM/SME, school, government office or corporate in rural or sub-urban areas that are not covered by ADSL cable services, optical fiber or high speed mobile access. At this time, VSAT IP Broadband Quota provides speed up to 2 Mbps and up to $6 \mathrm{Mbps}$. Not only internet connection, VSAT IP Broadband Quota also provides bonus like free STB TV as an edutainment media with various TV channels.

The advantage of VSAT IP Broadband Quota is the ability to provide service according to SLA to satisfy customer and after sales service handling.

Price according to Kotler and Keller (2016), price is good or service value measured by an amount of money based on the someone or company value is ready to release the goods or service to others. Loyal customer will notice the price. According to Kotler and Keller (2012), that dimension consists of: (1) Affordability of price, it means the flexible price and affordable by consumers. (2) Price policy is a 
dimension that price is not burdensome and convenience in making payment. (3) Price competitiveness is the dimension that the price can compete competitively. (4) Conformity is the dimension that the price suitable with the benefit.

The effect of price provides a new illustration of communication and marketing strategy to increase customer satisfaction. The price formula for satisfaction that there are two principles of price mechanism, it is potential to mark quality of product. Sale of high-quality product is characterized by high quality product. If the relationship between high cost and high quality is known, consumer can expect that high price has high quality.

Quality of Service. According to Parasuraman cited by Tjiptono (2011:198) that there are five main dimensions in service quality as follows : (1) Reliability. Company's ability to provide accurate services from the first time without making any mistakes and delivering services suitable to agreed time. Responsiveness related to readiness and ability of employees to help consumers and respond the requests, inform when services will be provided and provide the service quickly. (3) Assurance, behaviour of employees who are able to make grow consumer confidence in the company and the company can create a sense of security for customer. Assurance is that the employees are always polite and master the knowledge and skills to handle customer question or problem. (4) Empathy is that company understands the customer problems and acts for customer, give attention to customer and has comfortable operating hours. (5) Tangible is attractiveness of physical facilities, complete facilities, and appearance of employees. Based on the five dimensions of service quality, customer satisfaction can be measured, understood and used as good result to increase quality of service to customer, both first time customer and customer who have repeatedly used the service.

Brand Image. According to Kotler and Keller (2012:347), brand image has dimensions as follows : (1) Excellence of brand association, one of factors forming brand image is product excellence, the product is excellence in competition. (2) Strength of brand association, every valuable brand has a soul, a special personality is a fundamental responsibility for brand owner to express, socialize the soul/personality in an advertisement, promotion and other marketing. That is a link between product/brand and customer. Build the popularity of a brand to be a famous brand is not easy. However, popularity is one of keys that can shape a brand image to customer. (3) Uniqueness of brand association is the uniqueness that is owned by the product. Based on the definition of experts about brand, can be concluded that brand is an identity of a brand that offered to customer that can distinguish product in the company from competitor like name, word, symbol, design, or combination.

Customer Satisfaction. According to Oliver (Hurriyati, 2010:129) that the key to maintain customer is customer satisfaction, the dimensions of customer satisfaction are : (1) Expectation is customers are satisfied if the product according to the expectation. (2) Subjective Disconfirmation is customers are satisfied if there is no problem related to product. (3) Performance Outcomes is customers are satisfied if the product performance is optimal benefit.

Previous Research. Based on the journal citations of previous research, there are 3 variables, price, and quality of service and brand image that affect customer satisfaction. (1) N. Paramananda (2018) The Impact of Price Perception and Brand Image on Customer Satisfaction and Repurchase Intention. The result showed that price and brand image had a positive and significant impact to customer satisfaction and intention to buy (2) Mohamad Dimyati (2016) Impact of Service Quality, Price, and Brand on Loyalty with the mediation of Customer Satisfaction o Pos Ekspres in East Java. The result showed that quality of service, price, and brand image had a positive and significant impact to customer satisfaction and customer loyalty. (3) Andress Hamenda (2018) An Integrated Model of Service Quality, Price Fairness, Ethical Practice and Customer Perceived Values for Customer Satisfaction of Sharing Economy Platform. The result showed that quality of service, price feasibility, and ethical practice had a positive and significant impact to customer satisfaction. (4) Muhammad Usman (2017) The Impact of Customer Satisfaction on Price Sensitivity in Courier Services Sector. The result showed that quality of service had a positive and significant impact to customer satisfaction and price sensitivity (5) Kevin Simon (2016) The Effect of Service Quality to Customer Satisfaction of Surya Nalendra Sejahtera Tours \& Travel. The result showed the dimensions of service quality is tangible, reliability, responsiveness, assurance, empathy simultaneously affect customer satisfaction. The result showed that quality of service had a positive and significant impact to customer satisfaction and company image and company loyalty (6) Didit Darmawan (2018) The Effect of Service Quality Customer Satisfaction and Corporate Image on Customer Loyalty in the banking sector in Indonesia. The 
result showed that quality of service had a positive and significant impact to customer satisfaction and company image and company loyalty. (7) Tran Van Quyet (2015) Service Quality Effects on Customer Satisfaction in Banking Industry. The result showed that quality of service had a positive and significant impact to customer satisfaction in Vietnam. (8) Diah Yulisetiarini (2019) The Effect of Price, Service Quality, Customer Value, and Brand Image on Customer Satisfaction of Telkomsel Cellular Operators in East Java Indonesia. The result showed that price, quality of service, customer value, brand image had a positive and significant impact to customer satisfaction. (9) R. Neupane (2015) The Effects of Brand Image on Customer Satisfaction and Loyalty Intention in Retail Super Market Chain UK. The result showed that brand image had a positive and significant impact to customer satisfaction and customer loyalty. (10) M. Ali Iqbal (2018) Analysis of the Influence of Brand Image and Customer Value on Customer Satisfaction and Its Impact on Customer Loyaltys. The result showed that brand image and customer value had a positive and significant impact to customer satisfaction and customer loyalty.

Framework. Based on the previous research, relationship of price variable to customer satisfaction According to Diah Yulisetiarini (2019) that price, quality of service, customer value, brand image have an effect to customer satisfaction, Mandang Cristo (2017) that price, quality of service, physical environment to customer satisfaction, Muhammad
Usman (2017) that quality of service, price sensitivity have an effect to customer satisfaction, and Mohammad Dimyati (2016) that quality of service, price, brand image have an effect to customer satisfaction and customer loyalty. The relationship of service quality variable to customer satisfaction by journal of Kevin Simon (2016) that quality of service have an effect to customer satisfaction, Didit Darmawan (2018) that quality of service, company image have an effect to customer satisfaction and loyalty, Tran Van Quyet (2015) that quality of service have an effect to customer satisfaction, Goli Safikhani (2017) that quality of service have an effect to customer satisfaction and loyalty. The relationship of brand image variable to customer satisfaction described in the journal of Djumarni (2017) that brand image, quality of service, and marketing relationship to customer satisfaction and loyalty, R. Neupane (2015) that brand image to customer satisfaction and loyalty, Diah Yulisetiarini (2019) that quality of service, brand image have an effect to customer satisfaction, Rizwan Ali (2015) that customer expectation, corporate brand and service quality to customer satisfaction and Putro R.et all (2016) that brand image to customer satisfaction, customer loyalty. Therefore, dimension between the dependent variable and independent variable in this research that have not been reviewed in previous research are the independent variable, like price, quality of service, and brand image of Metrasat VSAT IP Broadband Quota and dependent variable is Customer Satisfaction.

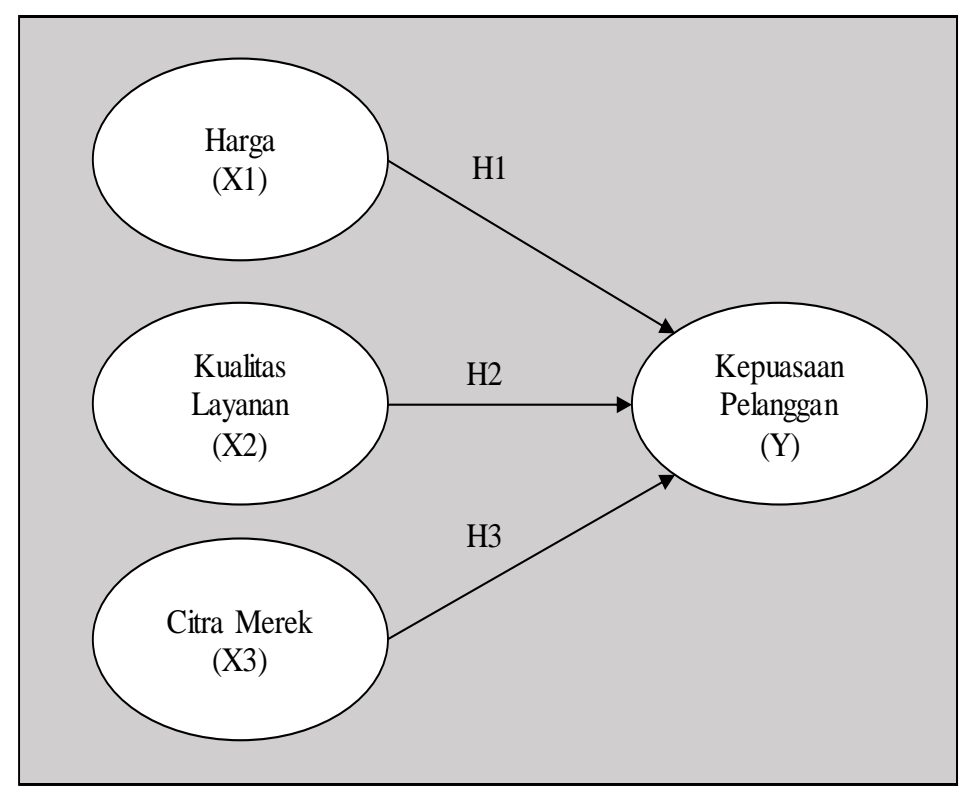

Figure 5. Research Model

Source : Data diolah, 2019 


\section{RESEARCH METHODS}

Research Design. Type of research is quantitative verification research use explanatory survey to examine a specific population in PT Telkom Satellite Indonesia customer. Instrument survey use questionnaire and data analysis use SEM (Structural Equation Modelling) to process data and then hypothesis test to find the effect of independent variable (X) on dependent variable (Y).

Operational Definition and Variable Measurement. Variable for this research is 3 independent variables and 1 dependent variable. (1) Independent Variable $(X):(X 1)=$ Price $(X 2)=$ Quality of Service $(X 3)=$ Brand Image (2) Dependent Variable $(\mathrm{Y}):(\mathrm{Y})=$ Customer Satisfaction .

Population and Sampling. Population for this research is Alfamart retail customer in Java branch who has used the VSAT IP Broadband Quota product for 3 years. Based on the management information of PT Telkomsat, total of Alfamart retail customer is 646 customers in Java.

\begin{tabular}{cccc}
\multicolumn{3}{c}{ Table 3. Link Data of VSAT IP Broadband Quota in Java } \\
\hline No & Retail Customer & $\begin{array}{c}\text { Number of } \\
\text { Population }\end{array}$ & Percentage \\
\hline 1 & Alfamart Balaraja & 169 & $26.16 \%$ \\
2 & Alfamart Serang & 107 & $16.56 \%$ \\
3 & Alfamart Cianjur & 79 & $12.23 \%$ \\
4 & Alfamart Cikokol & 59 & $9.13 \%$ \\
5 & Alfamart Parung & 44 & $6.81 \%$ \\
6 & Alfamart Karawang & 32 & $4.95 \%$ \\
7 & Alfamart Cileungsi 2 & 29 & $4.49 \%$ \\
8 & Alfamart Bogor & 27 & $4.18 \%$ \\
9 & Alfamart Bandung 2 & 22 & $3.41 \%$ \\
10 & Alfamart Bandung 1 & 19 & $2.94 \%$ \\
11 & Alfamart Malang & 12 & $1.86 \%$ \\
12 & Alfamart Bekasi & 11 & $1.70 \%$ \\
13 & Alfamart Semarang & 11 & $1.70 \%$ \\
14 & Alfamart Cilacap & 8 & $1.24 \%$ \\
15 & Alfamart Klaten & 6 & $0.93 \%$ \\
16 & Alfamart Sidoarjo & 6 & $0.93 \%$ \\
17 & Alfamart Rembang & 5 & $0.77 \%$ \\
\hline & Total & 646 & $100 \%$ \\
\hline
\end{tabular}

Source : Data Metrasat (2019)

Based on the analysis result, there are 646 retail customers of Alfamart in Java. Sampling method use part of probability sampling is satisfied random sampling. Sampling processed by strata/level. Determination of sample refers to Slovin formula with precision level 5\%, total sample is 248 respondents. 
Table 4. Sample of Alfamart Jabodetabek Area

\begin{tabular}{ccccc}
\hline No & Retail Customer & Location & $\begin{array}{c}\text { Number of } \\
\text { Population }\end{array}$ & $\begin{array}{c}\text { Number } \\
\text { of } \\
\text { Sample }\end{array}$ \\
\hline 1 & Alfamart Balaraja & Jabodetabek & 169 & 94 \\
2 & Alfamart Serang & Jabodetabek & 107 & 59 \\
3 & Alfamart Cikokol & Jabodetabek & 59 & 33 \\
4 & Alfamart Parung & Jabodetabek & 44 & 24 \\
5 & Alfamart Cileungsi 2 & Jabodetabek & 29 & 17 \\
6 & Alfamart Bogor & Jabodetabek & 27 & 15 \\
7 & Alfamart Bekasi & Jabodetabek & 11 & 6 \\
\hline \multicolumn{5}{c}{ Total } \\
\multicolumn{7}{c}{ Source : Data diolah (2019) } \\
\end{tabular}

Data Collection Methods. Primary data with total Alfamart customer is 248 customers who use internet service VSAT IP Broadband Quota by questionnaire survey and Secondary data from the agency and related sources (website and print media). The data collection method is field research method which means read the literature books. Secondary data aims to strengthen the primary data.

Table 5. Data Collection

\begin{tabular}{ccccc}
\hline No & Data & Type of Data & Data Source & $\begin{array}{c}\text { Collection } \\
\text { Method }\end{array}$ \\
\hline 1 & $\begin{array}{c}\text { Primary } \\
\text { Data }\end{array}$ & Pre Survey & $\begin{array}{c}\text { Owner } \text { and Retail } \\
\text { Manager of Alfamart } \\
\text { Java }\end{array}$ & $\begin{array}{c}\text { Questionnaire } \\
\text { survey }\end{array}$ \\
\hline & $\begin{array}{c}\text { Secondar } \\
\text { y Data }\end{array}$ & $\begin{array}{c}\text { Internet user, } \\
\text { indicator, } \\
\text { Vendor } \\
\text { competition }\end{array}$ & $\begin{array}{c}\text { Katadata, scientific } \\
\text { journals, internal } \\
\text { document of company }\end{array}$ & $\begin{array}{c}\text { Document from } \\
\text { related website }\end{array}$ \\
\hline \multicolumn{4}{c}{ Source : Data diolah (2019) }
\end{tabular}

Data Analysis Method. (1) Descriptive statistic test to get value of min, max, mean, and standard deviation to measure data distribution. (2) Model evaluation in PLS - SEM. According to Haryono (2017) that the model evaluation in PLS consists of 2 stages, outer model or measurement model and inner model or structural measurement. Evaluation of measurement model is classified to reflective and formative model. Model evaluation of PLS - SEM. 


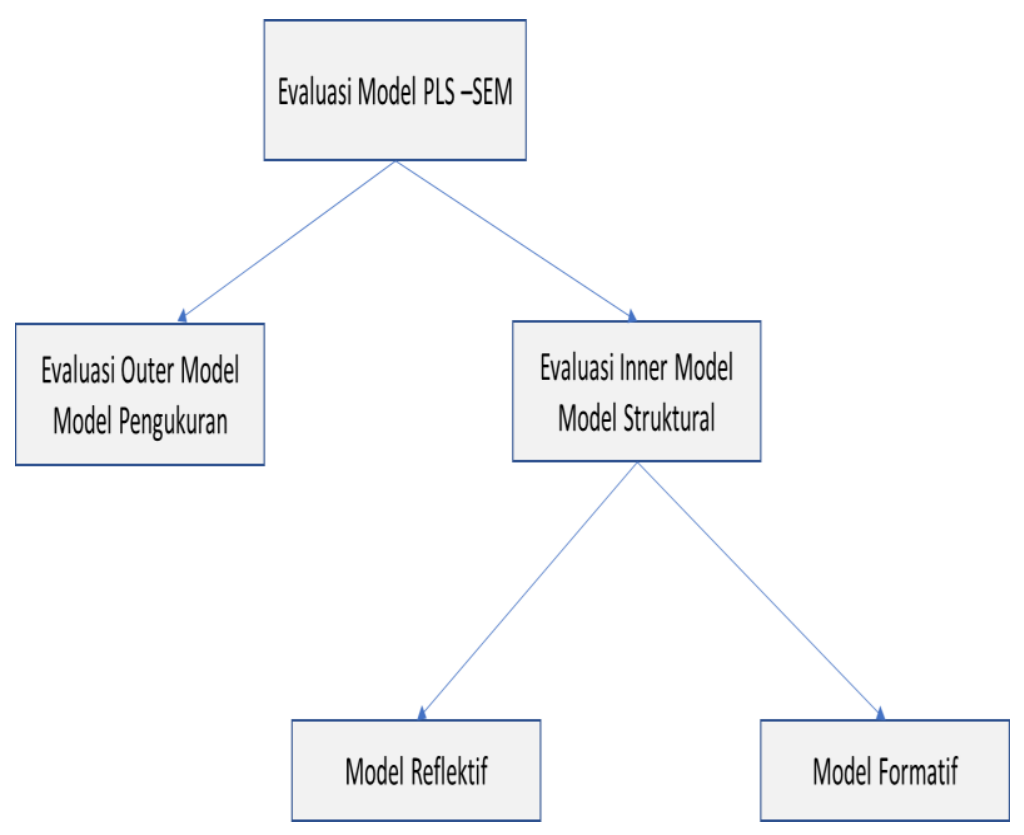

Figure 6. Model Evaluation of PLS - SEM

Source : Haryono (2017)

Explanation for evaluation PLS-SEM model, as follows. (1) Evaluation of Measurement Model (Outer Model) is also called outer relation defines how each indicator block relates to its latent variable. (a) Convergent Validity according to Ghozali and Latan (2015) that Convergent Validity test from each construct indicator. An indicator is valid if the value more than 0.60 , and loading factor less than 0.60 , it will be dropped from the model. AVE $>0.5$ is reliable. (b) Discriminant Validity according to Ghozali and Latan (2015) that discriminant validity relates to the principle of different construct manifestos should not be highly correlated. The method to test cross loading each variable must be $>0.70$. Another method to test discriminant validity is compare square root from AVE for each construct with correlation value between construct in the model. (c) Composite Reliability according to Ghozali and Latan (2015) that composite reliability aims to simulate the reliability of instrument. If all latent variable values have composite reliability $\geq 0.6$ and Cronbach alpha $>0.6$, it means that the construct has good reliability, and reliable or consistent questionnaire.

(2) Structural model or Hypothesis Test (Inner Model) is a development of model based on theoretical concept to analyze the relationship between exogenous and endogenous variable. Inner model test to find $\mathrm{R}$ Square value is also called goodness-fit test. Simulation stage, as follows : (a) Ttest as hypothesis test in research. Result/output Smart PLS from Bootstrapping generate $\mathrm{T}$ statistic. Indicator that has a $T$ Statistic $\geq 1.96$ is valid. Indicator is valid if have $P$ value $\leq$ 0.05 (Haryono, 2017). (b) Bootstrap method has been developed by Efron (1979) as a tool to help reduce the unreliability related to usage error of normal distribution. In bootstrap made a pseudo data use information and character from original data, so the pseudo data has similar characteristic to original data. In the bootstrap method, sampling from data sample (resampling with replacement) according to Ghozali and Latan (2015). (c) R2 (Square Multi Correlation) according to Widarjono (2010) in Haryono (2017) after the parameter significance test and show the significance, the next step is to find variance latent variable value analyze indicator variable. The squared multiple correlation coefficient (R2) to find variance value latent variable analyze indicator. Recommended $\mathrm{R} 2$ value is 0.67 (strong structural model), 0.33 (moderate structural model) and 0.19 (weak structural model).

\section{RESULT AND DISCUSSION}

Research Result. This research aims to analyze the Effect of Price, Quality of Service, Brand Image on the Customer Satisfaction to Internet Product VSAT IP Broadband Quota Mangoesky PT Telkomsat. Data collection process by instrument distribution with questionnaire to 248 Alfamart stores Jabodetabek area that use Mangoesky product. 
Characteristic of Customer Description. The Alfamart branch related to customer satisfaction using characteristic is working time, position and location or VSAT IP Broadband Quota product.

(1) Respondent Description Based On Working Time in Alfamart

Table 6. Working Time

\begin{tabular}{ccc}
\hline $\begin{array}{c}\text { Working } \\
\text { Time }\end{array}$ & $\begin{array}{c}\text { Number of } \\
\text { Respondent }\end{array}$ & Percentage \\
\hline$<3$ Years & 211 & $85.08 \%$ \\
$4-7$ & 31 & $12.50 \%$ \\
Years & & $1.61 \%$ \\
$8-11$ & 4 & $0.81 \%$ \\
Years & 2 & $100 \%$ \\
$>11$ Years & 248 & \\
\hline Total & \multicolumn{2}{c}{ Source: Hasil Pengolahan Data $(2019)$}
\end{tabular}

(2) Respondent Description Based On Position in Alfamart

Table 7. Position

\begin{tabular}{cc}
\hline Position & $\begin{array}{c}\text { Number of } \\
\text { Respondent }\end{array}$ \\
\hline Manager IT & 2 \\
IT Store & 6 \\
COS (Chief Of & 155 \\
Store) & \\
ACOS (Assistant & 85 \\
Chief Of Store) & 248 \\
\hline Total & \\
\hline Source: Hasil Pengolahan Data (2019)
\end{tabular}

(3) Respondent Description Based On Alfamart Location

Table 8. Location

\begin{tabular}{ccc}
\hline Location & $\begin{array}{c}\text { Number of } \\
\text { Respondent }\end{array}$ & Percentage \\
\hline Balaraja & 94 & $37.90 \%$ \\
Serang & 59 & $23.79 \%$ \\
Cikokol & 33 & $13.31 \%$ \\
Parung & 24 & $9.68 \%$ \\
Cileungsi & 17 & $6.85 \%$ \\
Bogor & 15 & $6.05 \%$ \\
Bekasi & 6 & $2.42 \%$ \\
\hline Total & 248 & $100 \%$ \\
\hline \multicolumn{2}{c}{ Source: Hasil Pengolahan Data $(2019)$}
\end{tabular}

Result of Descriptive Statistic Test. Product price has value minimum 8, maximum 40, mean 28.21 and standard deviation 5.03. Quality of service has value minimum 10, maximum 50, mean 36.70 and standard deviation 5.03, Brand Image has value minimum 8, maximum 30, mean 22.75 and standard deviation 2.75. Customer Satisfaction has value minimum 9 , maximum 30, mean 22.05 and standard deviation 3.17. 
Table 9. Descriptive Statistic Test

\begin{tabular}{cccccc}
\hline Variable & N & $\begin{array}{c}\text { Minimu } \\
\text { m }\end{array}$ & Maximum & Mean & $\begin{array}{c}\text { Std. } \\
\text { Deviation }\end{array}$ \\
\hline Price & 248 & 8 & 40 & 28.21 & 5.03 \\
Quality of Service & 248 & 10 & 50 & 36.70 & 5.03 \\
Brand Image & 248 & 8 & 30 & 22.75 & 2.75 \\
$\quad \begin{array}{c}\text { Customer } \\
\text { Satisfaction }\end{array}$ & 248 & 9 & 30 & 22.05 & 3.17 \\
\hline
\end{tabular}

Source: Hasil pengujian kuiesioner dengan excel, 2019

SEM Analysis Use SmartPLS. This research use SEM analysis and AmartPLS Application version 3.0. Partial Least Square (PLS) is one of alternative method Structural Equation Modeling (SEM) that can be used to solve this problem (Haryono, 2017).

(1) Outer Model Evaluation. Evaluation of measurement model or outer model is to assess the validity and reliability model. Outer model with reflexive indicator by convergent validity and discriminant validity from the indicators and composite reliability for indicator block (Ghozali and Latan, 2015). Simulating for Outer Model Evaluation consists of :

(a) Validity Test 1 . Convergent validity test from each construct indicator according to Chin in Ghozali and Latan (2015), the indicator is valid if outer loading more than $>0.7$. 
Table 10. Validity Test I

\begin{tabular}{|c|c|c|c|}
\hline Variable & Indicator & $\begin{array}{c}\text { Outer } \\
\text { loading }\end{array}$ & Description \\
\hline \multirow[t]{8}{*}{ Price } & $\mathrm{HPl}$ & 0.719 & Valid \\
\hline & $\mathrm{HP} 2$ & 0.731 & Valid \\
\hline & HP3 & 0.740 & Valid \\
\hline & HP4 & 0.763 & Valid \\
\hline & HP5 & 0.827 & Valid \\
\hline & HP6 & 0.852 & Valid \\
\hline & $\mathrm{HP}$ ? & 0.750 & Valid \\
\hline & HPS & 0.544 & Not Valid \\
\hline \multirow{10}{*}{$\begin{array}{l}\text { Quality of } \\
\text { Service }\end{array}$} & $\mathrm{KLl}$ & 0.510 & Not Valid \\
\hline & $\mathrm{KL} 2$ & 0.716 & Valid \\
\hline & $\mathrm{KL} 3$ & 0.742 & Valid \\
\hline & KL4 & 0.701 & Valid \\
\hline & KL5 & 0.773 & Valid \\
\hline & KL 6 & 0.733 & Valid \\
\hline & $\mathrm{KL}$ ? & 0.767 & Valid \\
\hline & KL \& & 0.824 & Valid \\
\hline & KL9 & 0.775 & Valid \\
\hline & KL 10 & 0.758 & Valid \\
\hline \multirow[t]{6}{*}{$\begin{array}{l}\text { Brand } \\
\text { Image }\end{array}$} & $\mathrm{CMl}$ & 0.707 & Valid \\
\hline & CMD & 0.727 & Valid \\
\hline & $\mathrm{CMB}_{3}$ & 0.820 & Valid \\
\hline & CM:4 & 0.847 & Valid \\
\hline & CM.5 & 0.757 & Valid \\
\hline & CM6 & 0.649 & Not Valid \\
\hline \multirow[t]{6}{*}{$\begin{array}{l}\text { Customer } \\
\text { Satisfaction }\end{array}$} & $\mathrm{KPl}$ & 0.661 & Not Valid \\
\hline & $\mathrm{KP} 2$ & 0.822 & Valid \\
\hline & KP3 & 0.786 & Valid \\
\hline & $\mathrm{KP4}$ & 0.723 & Valid \\
\hline & $\mathrm{KP} 5$ & 0.824 & Valid \\
\hline & KP6 & 0.788 & Valid \\
\hline
\end{tabular}

Source: Hasil Penguji Kuisioner dengan SmartPLS versi 3.0,2019 


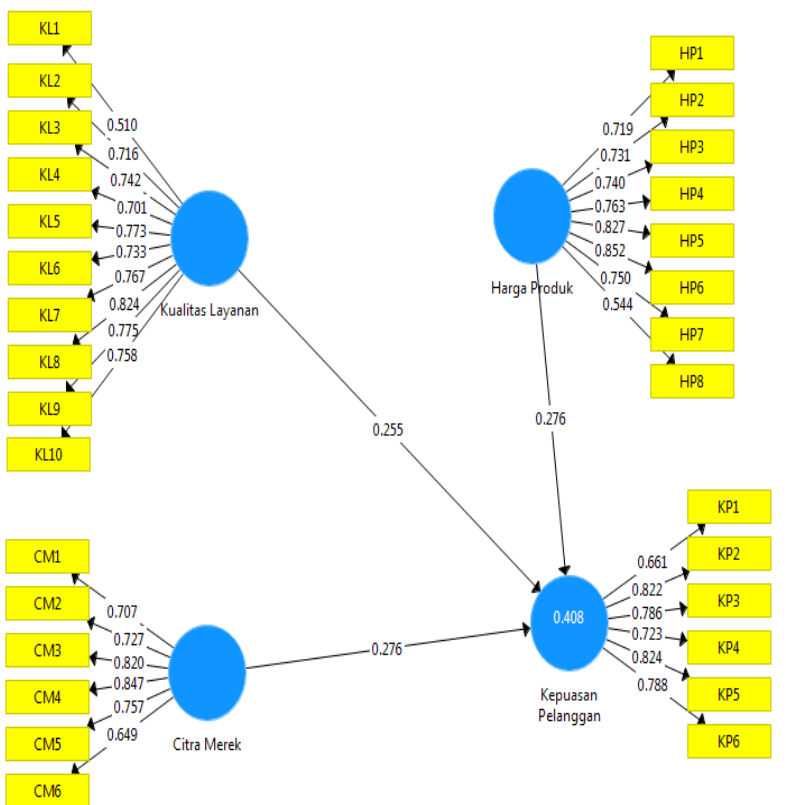

Figure 7. Preliminary Research Model

Source: Hasil Penguji Kuisioner dengan SmartPLS versi 3.0,2019

(b) Average Variance Extracted (AVE) Test I. Another method to assess discriminant validity is compare the square of AVE for each construct with correlation value between constructs in the model. The acceptable AVE value is more than 0.5 (Ghozali and Latan, 2015). AVE value of Price is valid 0.556 > 0.5, Quality of Service is valid 0.539 > 0.5, Brand Image is valid $0.569>0.5$, and Customer Satisfaction is valid $0.592>0.5$.

\begin{tabular}{ccc} 
Table 11. Result of Average Variance Extracted (AVE) Te & Average Variance \\
Variable & $\begin{array}{c}\text { Extracted }(\text { AVE }) \\
\text { Result }\end{array}$ \\
\hline $\begin{array}{c}\text { Price } \\
\text { Quality of } \\
\text { Service }\end{array}$ & 0.556 & Valid \\
Brand Image & 0.539 & Valid \\
$\begin{array}{c}\text { Customer } \\
\text { Satisfaction }\end{array}$ & 0.569 & Valid \\
\hline
\end{tabular}

Source: Hasil Pengujian Kuisioner dengan SmartPLS versi 3.0,2019

(c) Discriminant Validity Test I. Discriminant validity shows a construct is completely different from other variables. Discriminant validity from measurement model with reflective indicator that is assessed based on cross loading measurement with construct. 
Table 12. Result of Discriminant Validity Test I

\begin{tabular}{lllll}
\hline & Price & $\begin{array}{l}\text { Quality } \\
\text { of }\end{array}$ & $\begin{array}{l}\text { Brand } \\
\text { Image }\end{array}$ & $\begin{array}{l}\text { Customer } \\
\text { Satisfaction }\end{array}$ \\
\hline HP1 & 0.719 & 0.231 & 0.179 & 0.290 \\
HP2 & 0.731 & 0.227 & 0.190 & 0.289 \\
HP3 & 0.740 & 0.231 & 0.192 & 0.294 \\
HP4 & 0.763 & 0.294 & 0.257 & 0.391 \\
HP5 & 0.827 & 0.352 & 0.344 & 0.411 \\
HP6 & 0.852 & 0.341 & 0.339 & 0.383 \\
HP7 & 0.750 & 0.281 & 0.327 & 0.359 \\
HP8 & 0.544 & 0.338 & 0.306 & 0.375 \\
KL1 & 0.413 & 0.510 & 0.340 & 0.356 \\
KL2 & 0.247 & 0.716 & 0.321 & 0.311 \\
KL3 & 0.376 & 0.742 & 0.467 & 0.400 \\
KL4 & 0.222 & 0.701 & 0.375 & 0.341 \\
KL5 & 0.198 & 0.773 & 0.404 & 0.373 \\
KL6 & 0.212 & 0.733 & 0.351 & 0.313 \\
KL7 & 0.253 & 0.767 & 0.394 & 0.356 \\
KL8 & 0.360 & 0.824 & 0.464 & 0.418 \\
KL9 & 0.299 & 0.775 & 0.503 & 0.447 \\
KL10 & 0.275 & 0.758 & 0.456 & 0.438 \\
CM1 & 0.270 & 0.443 & 0.707 & 0.387 \\
CM2 & 0.159 & 0.394 & 0.727 & 0.339 \\
KM3 & 0.301 & 0.414 & 0.820 & 0.385 \\
KM4 & 0.308 & 0.461 & 0.847 & 0.406 \\
CM5 & 0.289 & 0.500 & 0.757 & 0.390 \\
CM6 & 0.316 & 0.336 & 0.649 & 0.431 \\
\hline KP1 & 0.369 & 0.343 & 0.412 & 0.661 \\
\hline KP3 & 0.414 & 0.418 & 0.428 & 0.822 \\
\hline & 0.328 & 0.330 & 0.311 & 0.723 \\
\hline & 0.472 & 0.474 & 0.824 \\
\hline & 0.462 & 0.453 & 0.788 \\
\hline
\end{tabular}

Source: Hasil Pengujian Kuiesioner dengan SmartPLS versi 3.0, 2019 
(d) Reliability Test I. According to Ghozali and Latan (2015) composite reliability test aims to simulate instrument reliability in a research model. If all latent variable values have composite reliability value $>0.6$ and Cronbach's alpha $>0.6$. All variables in this research model are reliable because composite reliability value $>0.6$. All variables in this research model are reliable because Cronbach's alpha value > 0.6 (Ghozali and Latan, 2015).

Table 13. Result of Composite Reliability Validity Test I

\begin{tabular}{ccl}
\hline Variable & $\begin{array}{c}\text { Composite } \\
\text { Reliability }\end{array}$ & Result \\
\hline Price & 0.908 & Reliable \\
Quality of Service & 0.920 & Reliable \\
Brand Image & 0.887 & Reliable \\
Customer & 0.896 & Reliable \\
Satisfaction & &
\end{tabular}

Source: Hasil Pengujian Kuesioner dengan SmartPLS versi 3.0, 2019

Table 14. Result of Cronbach's Alpha Validity Test I

\begin{tabular}{ccc}
\hline Variable & Cronbach Alpha & Result \\
\hline Price & 0.884 & Reliable \\
Quality of & 0.903 & Reliable \\
Service & 0.846 & Reliable \\
Brand Image & 0.861 & Reliable \\
Customer & & \\
Satisfaction &
\end{tabular}

Source: Hasil Pengujian Kuesioner dengan SmartPLS versi 3.0, 2019

(e) Validity Test II. All indicators have outer loading > 0.7. An indicator is valid if the value is more than 0.7 .

Table 15. Result of Validity Test II

\begin{tabular}{cccc}
\hline Variable & Indicator & Outerloading & Description \\
\hline \multirow{6}{*}{ Price } & HP1 & 0.759 & Valid \\
& HP2 & 0.762 & Valid \\
& HP3 & 0.758 & Valid \\
& HP4 & 0.782 & Valid \\
& HP5 & 0.847 & Valid \\
& HP6 & 0.860 & Valid \\
Quality of & HP7 & 0.701 & Valid \\
& KL2 & 0.706 & Valid \\
& KL3 3 & 0.729 & Valid \\
& KL5 & 0.704 & Valid \\
& KL6 & 0.790 & Valid \\
& KL7 & 0.750 & Valid \\
& & & Valid
\end{tabular}




\begin{tabular}{cccc}
\hline Variable & Indicator & Outerloading & Description \\
\hline & KL8 & 0.817 & Valid \\
& KL9 & 0.785 & Valid \\
& KL10 & 0.773 & Valid \\
& CM1 & 0.747 & Valid \\
Brand & CM2 & 0.774 & Valid \\
Image & CM3 & 0.849 & Valid \\
& CM4 & 0.861 & Valid \\
& CM5 & 0.726 & Valid \\
& KP2 & 0.791 & Valid \\
Customer & KP3 & 0.802 & Valid \\
Satisfaction & KP4 & 0.752 & Valid \\
& KP5 & 0.856 & Valid \\
& KP6 & 0.811 & Valid \\
\hline
\end{tabular}

Source: Hasil Pengujian Kuesioner dengan SmartPLS versi 3.0, 2019

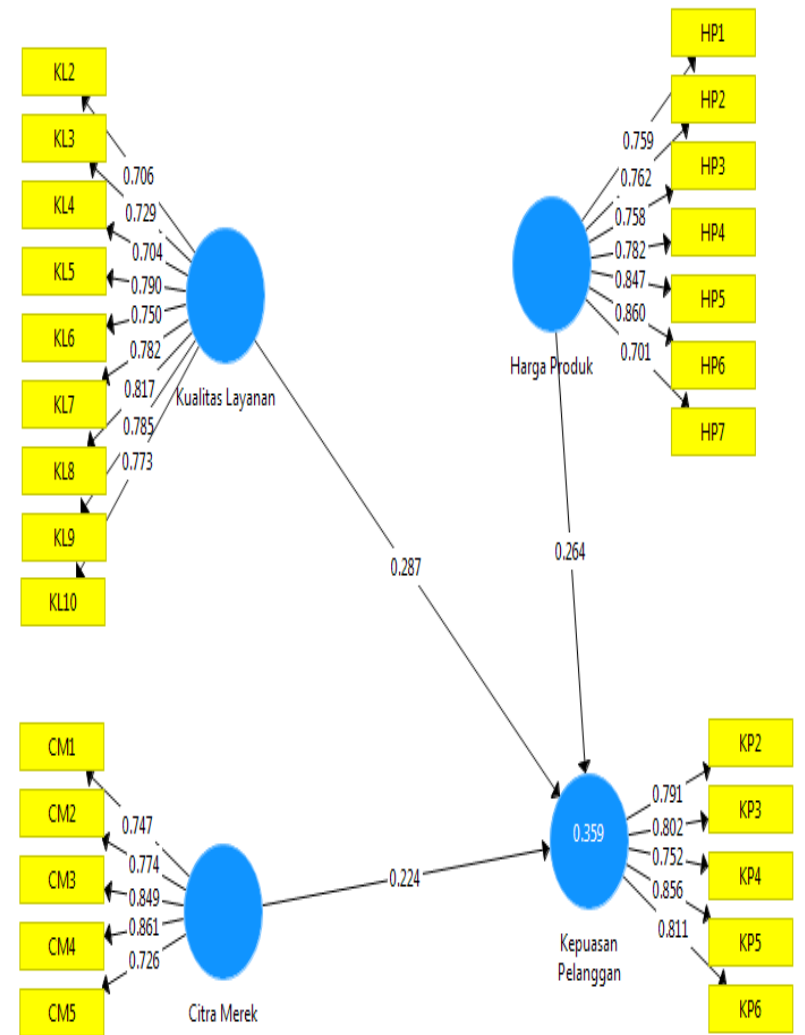

Figure 8. Validity Test 2

Source: Hasil Penguji Kuisioner dengan SmartPLS versi 3.0,2019

(f) Average Variance Extracted (AVE) Test II. Another method to assess discriminant validity is compare the square of AVE for each construct with correlation value between constructs in the model. The acceptable AVE value is more than 0.5 (Ghozali and Latan, 2015). AVE value of Price is valid $0.613>0.5$, Quality of Service is valid $0.578>0.5$, Brand Image is valid $0.629>0.5$, and Customer Satisfaction is valid $0.645>0.5$. 
Table 16. Result of Average Variance Extracted (AVE) Test II

\begin{tabular}{ccc}
\hline Variable & $\begin{array}{c}\text { Average Variance } \\
\text { Extracted }(\text { AVE })\end{array}$ & Result \\
\hline Price & 0.613 & Valid \\
$\begin{array}{c}\text { Quality of } \\
\text { Service }\end{array}$ & 0.578 & Valid \\
$\begin{array}{c}\text { Brand Image } \\
\text { Customer }\end{array}$ & 0.629 & Valid \\
Satisfaction & 0.645 & Valid
\end{tabular}

Source: Hasil Pengujian Kuisioner dengan SmartPLS versi 3.0,2019

(g) Discriminant Validity Test II. Discriminant validity shows a construct is completely different from other variables. Discriminant validity from measurement model with reflective indicator that is assessed based on cross loading measurement with construct. Be expected that measurement result of each latent variable compared to its indicator for other latent variables.

Table 17. Result of Discriminant Validity Test II

\begin{tabular}{lllll}
\hline & Price & Quality of Service & Brand Image & Customer Satisfaction \\
\hline HP1 & 0.759 & 0.220 & 0.157 & 0.285 \\
HP2 & 0.762 & 0.211 & 0.162 & 0.273 \\
HP3 & 0.758 & 0.210 & 0.157 & 0.276 \\
HP4 & 0.782 & 0.265 & 0.233 & 0.375 \\
HP5 & 0.847 & 0.327 & 0.322 & 0.400 \\
HP6 & 0.860 & 0.305 & 0.314 & 0.365 \\
HP7 & 0.701 & 0.252 & 0.302 & 0.335 \\
KL2 & 0.225 & 0.706 & 0.348 & 0.297 \\
KL3 & 0.363 & 0.729 & 0.461 & 0.377 \\
KL4 & 0.211 & 0.704 & 0.362 & 0.338 \\
KL5 & 0.170 & 0.790 & 0.407 & 0.382 \\
KL6 & 0.186 & 0.750 & 0.354 & 0.308 \\
KL7 & 0.226 & 0.782 & 0.381 & 0.353 \\
KL8 & 0.338 & 0.817 & 0.448 & 0.403 \\
KL9 & 0.280 & 0.785 & 0.490 & 0.445 \\
KL10 & 0.254 & 0.773 & 0.457 & 0.446 \\
CM1 & 0.253 & 0.413 & 0.747 & 0.371 \\
CM2 & 0.124 & 0.397 & 0.774 & 0.339 \\
CM3 & 0.285 & 0.407 & 0.849 & 0.371 \\
CM4 & 0.289 & 0.453 & 0.861 & 0.384 \\
CM5 & 0.269 & 0.499 & 0.726 & 0.367 \\
KP2 & 0.385 & 0.400 & 0.401 & 0.791
\end{tabular}




\begin{tabular}{llccc}
\hline & Price & Quality of Service & Brand Image & Customer Satisfaction \\
\hline KP3 & 0.405 & 0.334 & 0.261 & 0.802 \\
KP4 & 0.310 & 0.324 & 0.268 & 0.752 \\
KP5 & 0.276 & 0.463 & 0.458 & 0.856 \\
KP6 & 0.352 & 0.450 & 0.433 & 0.811 \\
\hline
\end{tabular}

Source: Hasil Pengujian Kuesioner dengan SmartPLS versi 3.0, 2019

(h) Reliability Test II. According to Ghozali and Latan (2015) composite reliability test aims to simulate instrument reliability in a research model. If all latent variable values have composite reliability value $>0.6$ and Cronbach's alpha > 0.6 , it means that the construct has good reliability and reliable or consistent questionnaire.

(i)

Table 18. Result of Composite Reliability Validity Test II

\begin{tabular}{ccl}
\hline Variable & $\begin{array}{c}\text { Composite } \\
\text { Reliability }\end{array}$ & Result \\
\hline Price & 0.917 & Reliable \\
Quality of Service & 0.894 & Reliable \\
Brand Image & 0.925 & Reliable \\
Customer & 0.901 & Reliable \\
Satisfaction & & \\
\hline
\end{tabular}

Source: Hasil Pengujian Kuesioner dengan SmartPLS versi 3.0, 2019

Table 19. Result of Cronbach's Alpha Validity Test II

\begin{tabular}{ccl}
\hline Variable & $\begin{array}{c}\text { Cronbach } \\
\text { Alpha }\end{array}$ & Result \\
\hline Price & 0.895 & Reliable \\
Quality of Service & 0.851 & Reliable \\
Brand Image & 0.909 & Reliable \\
Customer Satisfaction & 0.863 & Reliable
\end{tabular}

Source: Hasil Pengujian Kuesioner dengan SmartPLS versi 3.0, 2019

(2) Inner Model (Structural Model). Inner model test is development of model concept based and theory based to analyze the relationship of exogenous and endogenous variable which have been described in a conceptual (Ghozali and Latan, 2016). Inner model test, as follows:

(a) R Square (R2). R2 value is 0.359 which mean that part of moderate category.

Table 20. R2 Value Each Variable

\begin{tabular}{ccc}
\hline Variable & $\mathbf{R}^{\mathbf{2}}$ & Description \\
\hline $\begin{array}{c}\text { Customer } \\
\text { Satisfaction }\end{array}$ & 0.359 & Reliable
\end{tabular}

Source: Hasil Pengujian Kuesioner dengan SmartPLS versi 3.0, 2019 
(b) Effect Size (F2). Effect Size $\left(\mathrm{f}^{2}\right)$ value to evaluate whether without an exogenous variable has a substantive effect on the endogenous variable. F2 value is $0.02,0.15$, and 0.35 can be interpreted whether the latent variable predicator has small, medium, and large influence in the structural level according to Chin (1998) in Ghozali and Latan (2015). Price, Quality of Service and Brand Image have 0.094, 0.086 and 0.053 which have small effect on Customer Satisfaction.

\section{Table 21. Effect Size (F2) Value}

\begin{tabular}{|c|c|c|c|}
\hline $\begin{array}{c}\text { Exogenous } \\
\text { Variable }\end{array}$ & $\begin{array}{c}\text { Endogenous } \\
\text { Variable }\end{array}$ & $\begin{array}{c}\text { Effect } \\
\text { Size }\end{array}$ & Description \\
\hline Price & $\begin{array}{c}\text { Customer } \\
\text { Satisfaction }\end{array}$ & 0.094 & Small \\
\hline $\begin{array}{l}\text { Quality of } \\
\text { Service }\end{array}$ & $\begin{array}{c}\text { Customer } \\
\text { Satisfaction }\end{array}$ & 0.086 & Small \\
\hline $\begin{array}{l}\text { Brand } \\
\text { Image }\end{array}$ & $\begin{array}{c}\text { Customer } \\
\text { Satisfaction }\end{array}$ & 0.053 & Small \\
\hline
\end{tabular}

Source: Hasil Pengujian menggunakan SmartPLS versi 3.0, 2019

(c) Result of Predictive Relevance (Q2). Q-square indicates how the observation value produced by the model and also the estimated parameters. Range of Q2 value is $0<\mathrm{Q} 2<1$, getting closer to 1 that means the model is getting better. Q2 is equivalent to coefficient of total determination in path analysis. Q2 $>0$ indicates the model has predictive relevance, otherwise if the Q2 value $\leq 0$ indicates the model lacks predictive relevance. Q-Square $=1-[(1-\mathrm{R} 2)]=1-[1-0.359)]=1-$ $0.641=0.359$. Q-Square is 0.359 . This shows that the diversity of research data is $35.9 \%$ and $64.1 \%$ and others is not explained in this research.

(d) Hypothesis test. Hypothesis test use t-statistic coefficient. Input/output of bootstrapping is t-statistic. Indicator that has a tstatistic > 1.96, means significant (Ghozali and Latan, 2015). Indicator is called influential if p-value $<0.05$ (Haryono, 2017 ).

Table 22. Hypothesis Test

\begin{tabular}{|c|c|c|c|c|c|c|}
\hline Path & $\begin{array}{c}\text { Original } \\
\text { Sample }(\mathrm{O})\end{array}$ & $\begin{array}{c}\text { Sample } \\
\text { Mean (M) }\end{array}$ & $\begin{array}{c}\text { Standard } \\
\text { Deviation } \\
\text { (STDEV) }\end{array}$ & $\begin{array}{c}\text { T Statistics } \\
\text { (|O/STDE } \\
\text { V|) }\end{array}$ & $\begin{array}{c}P \\
\text { Values }\end{array}$ & Result \\
\hline $\begin{array}{c}\text { Price }->\text { Customer } \\
\text { Satisfaction }\end{array}$ & 0.264 & 0.258 & 0.054 & 4.905 & 0.000 & $\begin{array}{c}\text { Significa } \\
\mathrm{nt}\end{array}$ \\
\hline $\begin{array}{l}\text { Quality of Service -> } \\
\text { Customer Satisfaction }\end{array}$ & 0.287 & 0.278 & 0.083 & 3.450 & 0.001 & $\begin{array}{c}\text { Significa } \\
\mathrm{nt}\end{array}$ \\
\hline $\begin{array}{c}\text { Brand Image -> } \\
\text { Customer Satisfaction }\end{array}$ & 0.224 & 0.243 & 0.085 & 2.634 & 0.009 & $\begin{array}{c}\text { Significa } \\
\mathrm{nt}\end{array}$ \\
\hline
\end{tabular}

Source: Hasil Pengujian menggunakan SmartPLS versi 3.0, 2019

Result of Hypothesis test the research model: Hypothesis 1 Price to Customer Satisfaction, Price has t-statistic $4.905>$ 1.96 , p-value $0.000<0.05$ and original sample 0.264 , so the $\mathrm{H} 1$ is accepted, it means that Price has positive and significant effect on Customer Satisfaction. Hypothesis 2 Quality of Service to Customer Satisfaction, Quality of Service has t-statistic $3.459>1.96$, p-value $0.001<0.05$ and original sample 0.287 , so the $\mathrm{H} 2$ is accepted; it means that Quality of Service has positive and significant effect on Customer Satisfaction.

Hypothesis 3 Brand Image to Customer Satisfaction, Brand Image has t-statistic $2.634>1.96$, p-value $0.009<0.05$ and original sample 0.224 , so the $\mathrm{H} 2$ is accepted, it means that 
Brand Image has positive and significant effect on Customer Satisfaction.

\section{Discussion of Research Result}

(1) The effect of Price to Customer Satisfaction

Price has t-statistic $4.905>1.96$, p-value $0.000<0.05$ and original sample 0.264 , so the H1 is accepted; it means that Price has positive and significant effect to Customer Satisfaction. If the Price increases, then increase the Customer Satisfaction.

(2) The effect of Quality of Service to Customer Satisfaction Quality of Service has t-statistic $3.450>1.96$, p-value 0.001 $<0.05$ and original sample 0.287 , so the $\mathrm{H} 2$ is accepted, it means that Quality of Service has positive and significant effect to Customer Satisfaction. If the Quality of Service increases, then increase the Customer Satisfaction.

(3) The effect of Brand Image to Customer Satisfaction Brand Image has t-statistic $2.634>1.96$, p-value $0.009<$ 0.05 and original sample 0.224 , so the H3 is accepted, it means that Brand Image has positive and significant effect to Customer Satisfaction. If the Brand Image increases, then increase the customer satisfaction.

\section{CLOSING}

Conclusion. The research aims to find the effect of price, quality of service and brand image to customer satisfaction in using internet service VSAT IP Broadband Quota. Based on the data analysis and discussion, as follows :
(1) Price has positive and significant effect to Customer Satisfaction in using internet product VSAT IP broadband quota PT Telkomsat Metrasat division.

(2) Quality of Service has positive and significant effect to Customer Satisfaction in using internet product VSAT IP broadband quota PT Telkomsat Metrasat division.

(3) Brand Image has positive and significant effect to Customer Satisfaction in using internet product VSAT IP broadband quota PT Telkomsat Metrasat division.

Suggestion. Suggestion to increase Customer Satisfaction, as follows :

(1) Price has positive and significant on customer satisfaction. The strongest relationship is price competitiveness dimension. Suggestion for the company is to maintain price competitiveness against competitors by not letting down the quality of service to maintain customer satisfaction.

(2) Quality of Service has positive and significant on customer satisfaction. Suggestion for the company on the empathy dimension is to improve the competency of aftersales and equip PT Telkomsat's company internal employees in the Metrasat division especially care center and network operation control with product knowledge so that the service network problem can be resolved very well.

(3) Brand Image has positive and significant effect on customer satisfaction. Suggestion for the company in uniqueness dimension is to expand customer socialization related to transaction security.

\section{REFERENCES}

[1] Adi, Putro dan Rachmat Basuki. (2019). "Effect of Brand Image and Service Quality on Customer Satisfaction and Loyalty at Bank Jatim Syariah Surabaya". Russian Journal of Agricultural and Socio-Economis Sciences, Vol.3, No.87.

[2] Ali, Rizwan; Gao L, Muhammaaad YR, dan Mudassar H. (2015). "Role of Perceived Value, Customer Expectation, Corporate Image and Perceived Service Quality on the Customer Satisfaction". Journal of Applied Business Research, Vol.31, No.4.

[3] Achmad, F dan Supriono, S. (2017). Pengaruh Persepsi Harga dan Kualitas Layanan terhadap Minat Pembelian Ulang (Survei pada Konsumen Go-ride di Kota Surabaya). Journal Administrasi Bisnis, 50(2), hal 135-141.

[4] Cristo, Mandang; David P. E Saerang, dan Frederik G. Worang. (2017). "The Influence of Price, Service Quality, and Physical Environment on Customer Satisfaction. Case Study Markobar Cafe Mando”. Journal EMBA, Vol.5 No.2, hal $678-686$.

[5] Darmawan, Didit; Rahayu Mardikaningsih, dan Surjo Hadi. (2017). "The Effect of Service Quality, Customer Satisfaction and Corporate Image on Customer Loyalty in the banking sector in Indonesia". IOSR Journal of Business and Management (IOSR-JBM), Vol.19, No.11.

[6] Djumarno; Oktavian Sjafar, dan Said Djamaluddin. (2017). "The Effect of Brand Image, Product Quality, and Relationship Marketing on Customer Satisfaction and Loyalty". International Journal of Business Marketing and Management (IJBMM), Vol.2, No.10. 
[7] Fitriana, Dewi. (2014). "Pengukuran Kepuasan Kontraktor Terhadap Kinerja Klien Pada Proyek Konstruksi Swasta". Jurnal Karya Teknik Sipil. Vol. 3, No. 1.

[8] Hurriyati, Ratih. (2010). Bauran Pemasaran dan Loyalitas Konsumen. Alfabeta. Bandung.

[9] Iqbal, M. Ali; Yanti Murni, dan Niken Sulistyowanti. (2018). "Analysis of the Influence of Brand Image and Customer Value on Customer Satisfaction and its Impact on Customer Loyalty". International Journal of Economics, Business and Management Research, Vol.2, No.4.

[10] Jamaluddin, dan Endang Ruswanti. (2017). "Impact of Service Quality and Customer Satisfaction on Customer Loyalty: A Case Study in a Private Hospital in Indonesia". IOSR Journal of Business and Management (IOSR-JBM), Vol.19, No.5.

[11] Kotler, Philip dan Kevin Lane Keller. (2012). Manajemen Pemasaran. Erlangga. Jakarta.

[12] Kotler, Philip dan Kevin Lane Keller. (2016). Marketing Managements. Erlangga. Jakarta.

[13] Kotler, Philip dan Gary Armstrong. (2013). Prinsip-prinsip Pemasaran. Jilid 1 (Edisi 13). Jakarta.

[14] Neupane, Ramesh. (2015). "The Effects of Brand Image on Customer Satisfaction and Loyalty Intention in Retail Super Market Chain UK”. International Journal of Social Sciences and Management (IJSSM), Vol.2, No.1.

[15] Paramananda, N. (2018). "The Impact of Price Perception and Brand Image on Customer Satisfaction and Repurchase Intention". International Journal of Economics, Commerce and Management, Vol.VI, No.10.

[16] Peter, Paul J dan Olson Jerry C (2002). Consumer Behavior \& Marketing Strategy: Perilaku Konsumen dan Strategy Pemasaran. Jakarta

[17] Purnamasari, I.G.A Yulia. (2015). "Pengaruh Kualitas Produk dan Harga Terhadap Kepuasan Konsumen Produk M2 Fashion Online di Singaraja Tahun 2015". Jurnal Jurusan Pendidikan Ekonomi (JIP), Vol.5, No.1.

[18] Quyet, Tran Van; Nguyen Quang Vinh, dan Taikoo Chang. (2015). "Service Quality on Customer Satisfaction in Banking Industry". International Journal of u-and e-Service, Science and Technology, Vol.8, No.8.

[19] Razak, Ismail. (2016). "The Impact of Product Quality and Price on Customer Satisfaction with the Mediator of Customer Value". Journal of Marketing and Consumer Research, Vol.30.

[20] Simon, Kevin; Christina Whidya Utami, dan Metta Padmalia. (2016). "Pengaruh Kualitas Layanan Terhadap Kepuasan Pelanggan Surya Nalendra Sejahtera Tours \& Travel". Jurnal Manajemen dan Start-Up Bisnis, Vol.1, No.3.

[21] Sondakh, C. (2014). "Kualitas Layanan, Citra Merek dan Pengaruhnya terhadap Kepuasan Nasabah dan Loyalitas Nasabah Tabungan : Studi pada Nasabah Taplus BNI Cabang Manado”. Jurnal Riset Bisnis dan Manajemen. Vol.3.

[22] Sunyoto, Danang. (2012). Konsep Dasar Riset Pemasaran dan Perilaku Konsumen. CAPS (Center for Academic Publishing Service). Yogyakarta.

[23] Tee, Daniel Kasser; Alex Preko, dan Evans Tee. (2018). "Understanding the Relationships Between Service Quality, Customer Satisfaction and Loyalty: An Investigation of Ghana's Retail Banking Sector”. British Journal of Marketing Studies, Vol.6, No.2.

[24] Tjiptono, Fandy dan Gregorius Chandra. (2011). Service Quality \& Satisfaction. Andi. Yogyakarta.

[25] Tjiptono, Fandy. (2014). Pemasaran Jasa: Prinsip, Penerapan \& Penelitian. Andi. Yogyakarta.

[26] Tjiptono, Fandy dan Gregorius chandra. (2016). Service, Quality \& satisfaction. Andi. Yogyakarta.

[27] Usman, Muhammad dan Zia Ur Rehman. (2017). "The Impact of Customer Satisfaction on Price Sensitivity in Courier Services Sector". IOSR Journal of Humanities and Social Science (IOSR-JHSS), Vol.22, No.3.

[28] Yulisetiarini, Diah dan Yongki Ade Prahasta. (2019). "The Effect of Price, Service Quality, Customer Value, and Brand Image on Customers Satisfaction of Telkomsel Cellular Operators in East Java Indonesia". International Journal of Scientific \& Technology Research, Vol.8, No.3. (2018).

[29] Berapa Jumlah Pengguna Internet di Indonesia. https://databoks.katadata.co.id/datapublish/2018/02/20/berapa-jumlahpengguna-internet-di-indonesia (Diakses tanggal 12 Mei 2019). (2017).

[30] Berapa Jumlah Gerai Group Alfamart. https://databoks.katadata.co.id/datapublish/2017/11/20/berapa-jumlah-gerai-grupalfamart (Diakses tanggan 12 Mei 2019).

[31] (2018). Paket FIT. https://ubiqu.id/paket-fit/ (Diakses tanggal 12 Mei 2019). 